\title{
Molecular Characterization and Biocontrol-traits Evaluation of Trichoderma virens TVH3 against Fusarium oxysporum, the Causal Agent of Tomato wilt.
}

\author{
Alsayed Alfiky", Medhat Eldenary \\ Genetics Department, Faculty of Agriculture, Tanta University, Tanta, Egypt.
}

\begin{abstract}
NATTEMPT to screen for new biological control agents (BCA) with high activity against soil-borne fungal pathogens, an isolate of the BCA Trichoderma virens was obtained, identified using molecular techniques and named TVH3. The antagonistic activities of this isolate were tested against Fusarium oxysporum, a major soil-borne fungal pathogen of diverse crops. Our results revealed that $T$. virens TVH3 displayed high antagonistic potential against $F$. oxysporum via different mechanisms to control its prey, such mechanisms include competition for the available space and nutrients, mycoparasitism and production of antimicrobial secondary metabolites including volatile organic compounds (VOCs). The antifungal soluble metabolites in Trichoderma's culture filtrate were found to be thermal-stable and $T$. virens TVH3 was found to possess high natural immunity against antimicrobial metabolites in F. oxysporum culture filtrate. In the biocontrol assay, isolate T. virens TVH3 was applied as seed coat on tomato seeds before planting them in heavily infested soil with pathogenic strain of $F$. oxysporum and the obtained results revealed that such seed treatment had significantly reduced wilt signs on plants and provided the seedlings with effective shield against pathogenic infection.
\end{abstract}

Keywords: Biocontrol, Trichoderma, Fusarium, Biofungicide, Tomato, Wilt.

\section{Introduction}

Plant diseases pose great threat for global food security as they cause significant losses in agricultural and horticultural crops every year. Agrochemicals e.g. pesticides, insecticides and fungicides, were developed to enhance crop yields and protect crops from pests and pathogens. However, despite the great importance of agrochemicals in increasing food production and decreasing production costs (Damalas, 2009), their adverse effects on many aspects in the agricultural eco-system had been well proven and documented (Ridgway et al., 1978; Koh \& Jeyaratnam, 1996; Aktar et al., 2009 and Damalas, 2009). Such negative effects includes harm to soil fertility, surface and ground water contamination, non-targeted damage to ecosystem's fauna and flora, rise of resistant strains and severe negative effects on human health (Wauchope, 1978; Hollomon, 2015 and Lucas et al., 2015); hence, comes the need for more natural and environment-friendly approaches for crop protection. Biological control provides a safer and ecologically acceptable alternative to fungicide applications. The term biocontrol in this context refer to the use of microbial antagonists to control disease causing pathogens (Pal \& Gardener, 2006).

Commonly available in soil and root ecosystems, Trichoderma species have attracted immense importance for their wide-spread industrial applications, their biological control activity and positive effects on plant growth and yield (Harman et al., 2004). The success of Trichoderma as BCA scould be explained and attributed to their fortified genomic arsenal with different antimicrobial mechanisms, resistance to unfavorable conditions, powerful reproductive capacity, aggressiveness against pathogenic fungi in addition to their ability to stimulate plant growth and defense responses (Benítez et al., 2004; Harman et al., 2004; Ozbay et al., 2004; Hoitink et al., 2006; Geraldine et al., 2013; Nawrocka \& Małolepsza, 2013 and Vinale et al., 2014). 
Fusarium oxysporum is a soil-borne pathogen infecting wide range of crops causing severe agricultural damages worldwide (Rowe, 1980; Kai et al., 2007; McGovern, 2015 and Ploetz, 2015). Tomato (Solanum lycopersicum L.) is considered one of the most important vegetable crops in many countries in the world. Yield losses in tomato from Fusarium wilt can be very high considering the susceptible host-virulent pathogen combinations (McGovern, 2015). Chemical treatments through fungicides to control Fusarium wilt disease are not consistently effective because of its endophytic growth, persistence in soil for many years without host and for the physical and chemical heterogeneity of soil which may prevent effective concentrations of the chemicals from reaching to the pathogen (Snyder, 1974 and Ignjatov et al., 2012).

In this study, we screened soil samples searching for new BCAs with high antagonistic activities and improved biocontrol potential. The internal transcribed spacer polymerase chain reaction (ITS-PCR) was used to identify the obtained isolates and both lab and growth chamber studies were carried out to evaluate antagonistic activities and biocontrol potential of the isolate $T$. virens TVH3 against $F$. oxysporum.

\section{Materials and Methods}

\section{Plant and fungal cultures}

Three strains of F. oxysporum f. sp. lycopersici, including NRRL 54003 (FSK742), NRRL 34936 (FSK16) and NRRL 26381 (FSK737), were obtained from the ARS Culture Collection at the National Center for Agricultural Utilization Research in Peoria, IL. The BCA used in this study was $T$. virens TVH3 which was isolated from soil sample from the greenhouse of the College of Agricultural Science, Pennsylvania State University. Soil samples were collected and platedusing serial decimal dilutionson dichloran rose bengal chloramphenicol (DRBC; Difco, NJ) and potato dextrose agar (PDA; Difco, $\mathrm{NJ}$ ). Colonies were purified using single spore technique and the purified fungi were identified to the species level by sequence analysis of the internal transcribed spacer regions of the nuclear rDNA. Fungal cultures were preserved as spore suspension in $20 \%$ glycerol at $-80^{\circ} \mathrm{C}$ and were activated on PDA. Tomato cultivar Moneymaker (Eden Brothers Inc., NC, USA) was selected for the pathogenicity test in this study.
Molecular characterization and identification of $B C A s$

Genomic DNA extraction from the selected isolates

Fungal genomic DNA was extracted by culturing the fungi individually first in $250 \mathrm{ml}$ conical flasks containing $50 \mathrm{ml}$ potato dextrose broth (PDB; Difco, NJ) for 5 days at $25^{\circ} \mathrm{C}$ in darkness and shaking speed of 150rpm. Mycelia were harvested by filtration through Whatman filter paper (Whatman, NY, USA) and washed three times with distilled sterilized water. The genomic DNA was extracted using DNeasy plant mini kit (Qiagen) following the manufacturer's instructions.

\section{Qualitative and quantitative evalaution of gDNA}

Purity and concentration of extracted DNA were determined by means of spectrophotometry using NanoDrop (Thermo Scientific, USA) and its integrity by agarose gel electrophoresis in 1.0\% agarose gel in TAE $(40 \mathrm{mM}$ Tris, $1 \mathrm{mM}$ EDTA, $20 \mathrm{mM}$ acetic acid) for $60 \mathrm{~min}$ at $80 \mathrm{~V}$ using EZvision ${ }^{\circledR}$ (AMRESCO, USA) aslo ading and staining dye.

PCR amplification of ITS region of the selected isolates

Using universal primers ITS1 (TCCGTAGGTGAACCTGCGG) and ITS4 (TCCTCCGCTTATTGATATGC) (White et al., 1990), PCR reactionswere performed in a thermal cycler (PTC-100 MJ Research Inc., USA) in a total volume of $50 \mu \mathrm{l}$ containing $35.7 \mu \mathrm{l}$ deionized water, $5 \mu \mathrm{l}$ of 10X Ex Taq buffer, $4 \mu \mathrm{l}$ dNTPs mixture, $1 \mathrm{U}$ $(0.3 \mu \mathrm{l}) \mathrm{TaKaRa}$ Ex Taq polymerase, $2 \mu \mathrm{l}(10 \mathrm{pmol})$ of both forward and reverse primers and $1 \mu$ of template DNA. The PCR program comprised of an initial denaturation stepfor $5 \mathrm{~min}$ at $94^{\circ} \mathrm{C}$ followed by 36 cycles in series of denaturation at $95^{\circ} \mathrm{C}$ for $1 \mathrm{~min}$, annealing at $55^{\circ} \mathrm{C}$ for $1 \mathrm{~min}$, and extension at $72^{\circ} \mathrm{C}$ for $1 \mathrm{~min}$, with a final step of one cycle at $72^{\circ} \mathrm{C}$ for $10 \mathrm{~min}$. PCR amplification products were separated on $1.5 \%$ agarose gel prepared in $1 \mathrm{X}$ TAE buffer.

\section{PCR-product purification and sequencing}

PCR products were purified following the protocols of the QIAquick ${ }^{\circledR}$ PCR Purification Kit (Qiagen, CA). The purified DNA was eluted from spincolumns with $30 \mu \mathrm{l}$ of nuclease free $\mathrm{H}_{2} \mathrm{O}$ and then DNA concentrations were determined witha NanoDrop. Tubes containing DNA and primers were sent to the Genomic Core Facility, 
Pennsylvania State University for sequencing. In the final step to obtain species identity, the obtained sequences were blasted against known sequences deposited in the NCBI database available at http:// blast.ncbi.nlm.nih.gov/Blast.cgi. The obtained sequences were also analyzed using Trichoderma molecular barcode system available at (www.isth. info) for the molecular identification of Hypocreal Trichoderma at the genus and species levels (Druzhinina et al., 2005).

\section{Antagonistic assays}

Dual culture assay

Dual confrontations between the BCA T. virens TVH3 and $F$. oxysporum were conducted in $9 \mathrm{~cm}$ disposable sterile plastic Petri platescontaining $20 \mathrm{ml}$ of 0.75 strength PDA. Plates were inoculated with $5.0 \mathrm{~mm}$ discs of both the BCA and the pathogens from the edge of 4-7 days old cultures grown at $25^{\circ} \mathrm{C}$ under dark conditions. Mycelium discs were placedat $20 \mathrm{~mm}$ distance from the edge of the plate, opposed to each other and on the same diagonal line. Plates were incubated at $25 \pm 1^{\circ} \mathrm{C}$ in darkness and photographed periodically. Petri plates without the BCA served as controls. The experiment was carried out in triplicateand radial growth of each fungus was measured by a ruler. The percentage of pathogen growth inhibition was calculated using the following formula (Hajieghrari et al., 2008):

$$
\mathrm{I}(\%)=(\mathrm{C}-\mathrm{T}) / \mathrm{Cx} 100
$$

where, $\mathrm{I}=$ Percentage of inhibition, $\mathrm{C}=$ Colony diameter of pathogen in control, $\mathrm{T}=$ Colony diameter of pathogen in the presence of antagonist.

The effect of $T$. virens culture filtrate on $F$. oxysporum growth and the effect of $F$. oxysporum on $T$. virens growth (the reverse assay)

To investigate the antifungal properties of $T$. virens TVH3 culture filtrate on the growth of $F$. oxysporum strains, $50 \mathrm{ml}$ of Trichoderma minimum media (TMM) (Penttilä et al., 1987) in 250ml flasks were inoculated with $5 \mathrm{~mm}$ mycelium disc of one week old TVH3 grown on PDA. Flasks were incubated at $27^{\circ} \mathrm{C}$ and $150 \mathrm{rpm}$. After 6 days of incubation, the media were first filtered through filter paper and the liquid filtrate was sterilized by filtration through $250 \mathrm{ml}$ vacuum filtration system, pore size of $0.2 \mu \mathrm{m}$ (VWR, USA). By means of sterile pipetting, the calculated amount of the culture filtrate was incorporated into molten PDA medium (at $40 \pm 4^{\circ} \mathrm{C}$ ) to obtain a final concentration of $25 \%$ and $50 \%(\mathrm{~V} / \mathrm{V})$. Under aseptic conditions,
$20 \mathrm{ml}$ of the amended medium was transferred to $9 \mathrm{~cm}$ sterile Petri plates and allowed to solidify. Plates were inoculated at the center with $5 \mathrm{~mm}$ mycelium disc of Fusarium strains from the edge of one-week old culture and incubated at $25 \pm 1{ }^{\circ} \mathrm{C}$ for 6 days. Three replicates for eachtreatment were applied and the control treatment consisted of PDA medium amended with filtered noninoculated TMM incubated under same conditions. Radial growth measurements were recorded from the edge of the initial inoculum until the extreme area of fungal mycelia development. Inhibition of mycelial growth of $F$. oxysporum was recorded as the difference between mean radial growth in the presence and absence of the $T$. virens culture filtrate and was calculated using the above-mentioned formula.

Similarly, the effects of $T$. virens culture filtrate on $F$. oxysporum spore germination were assayed using amended media plates prepared following the same protocol. Plates were prepared and inoculated with $500 \mathrm{spore} / \mathrm{ml}$ of $F$. oxysporum spore solution adjusted to 500 spore $/ \mathrm{ml}$. The spore solution was equally distributed on the surface of the plates using sterilized glass beads. Three replicates for each concentration were prepared andthe control treatment consisted of PDA medium amended with filtered non-inoculated TMM incubated under the same conditions. Plates were incubated at $25 \pm 1{ }^{\circ} \mathrm{C}$ for $24 \mathrm{~h}$ before counting the germinated spores in all plates.

To investigate the nature of the antifungal compounds in Trichoderma culture filtrate and their heat stability, filtered broth was autoclaved at $121^{\circ} \mathrm{C}$ for $20 \mathrm{~min}$, and the same assay was carried out again using the autoclaved filtrate, active filtrate and control filtrate (non-inoculated TMM) at concentration of $50 \%$.

The reverse assay was also carried out to see the impact of $F$. oxysporum soluble metabolites at two different concentrations ( $25 \%$ and $50 \%$ ) on the growth of the BCA. F. oxysporum culture filtrate were prepared following the same protocolused for preparing Trichoderma culture filtrate.

The effect of Fusarium cell wall on T. virens anti-fungal activity

To investigate the effect of Fusarium cell wall (FCW) as sole carbon on $T$. virens antifungal activity, two different TMMs were prepared, either with $1.0 \%$ glucose or with $1.0 \% \mathrm{FCW}$ as the sole 
carbon source inmedium. To prepare FCW, F. oxysporum was first cultured in PDB for two weeks and autoclaved. Mycelia were collected by filtration through filter paper, washed thoroughly with sterile water, dried in oven at $70^{\circ} \mathrm{C}$ for overnight, grinded to fine powder in liquid nitrogen and tested for absence of colony-forming units (CFU). Modified TMM flasks were inoculated with mycelium disc of TVH3, incubated at $27^{\circ} \mathrm{C}$ and $165 \mathrm{rpm}$ for 6 days. Media were filtered through filter paper, sterilized by filtration and mixed with molten PDA at final concentration of $50 \%$ in $9 \mathrm{~cm}$ sterile Petri plates as previously explained. Plates were inoculated at the center with $F$. oxysporum FSK742, incubated for 6 days at $25^{\circ} \mathrm{C}$ and the radial growth measurements were taken after 6 days of incubation.

\section{The effect of T. virens VOCs on F. oxysporum spore germination}

The method of Dennis \& Webster (1971) was adapted for the VOCs mediated interactions. The sandwich system was assembled so fullygrown $T$. virens cultures would be incubated with freshly inoculated $F$. oxysporum spores. The sandwich systems comprised of $9 \mathrm{~cm}$ Petri plates containing $20 \mathrm{ml}$ PDA at $0.75 \mathrm{x}$ which was either centrally inoculated with $5 \mathrm{~mm}$ discs of $T$. virens and incubated for a week or inoculated with spore solution of $F$. oxysporum. Under aseptic conditions, the lids were removed, and the two-bottom portion of the Petri plates were placed facing each other with $T$. virens in the bottom plate and $F$. oxysporum spores at the top. The plates were sealed with 3 layers of Parafilm to avoid VOCs release and the plates were incubated for 6 days at $25 \pm 1^{\circ} \mathrm{C}$. Three replicates were performed, and the control treatment consisted of the same set-up with the bottom plates containing non-inoculated (empty) PDA medium. The numbers of germinated spores were counted in both the control and assay treatments.

\section{Pathogenicity test}

Pathogenicity test was carried out following the protocol of Sivan \& Chet (1987) with minor modifications. The test was performed with three strains of $F$. oxysporum $f$. sp. lycopersici in $10 \times 10 \times 10 \mathrm{~cm}$ plastic pots and one tomato seed was planted per pot. Seeding soil medium (Promix, a commercially available potting material, Premier Horticulture Inc., Quebec, Canada) was autoclaved twice at $121^{\circ} \mathrm{C}$ for $40 \mathrm{~min}$ on two consecutive days. Soil infestation with the pathogen was performed using conidial suspension of the pathogen. $50 \mathrm{ml}$ of $10^{6} \mathrm{conidia} / \mathrm{ml}$ spore suspension was well mixed with the seeding soil. The pathogenicity test contained a non-inoculated control by planting seeds in non-infested soil. The pots were placed in a growth chamber at $26^{\circ} \mathrm{C} / 21^{\circ} \mathrm{C}$ day/night with a $14 \mathrm{~h}$ photoperiod and watered on alternative days with plant nutrient solution (PNS), 3.748g/L using PETERS $^{\circledR}$ 20-20-20 all-purpose plant food (MO, USA). The test was carried out in a completely randomized design with three replicates. Each treatment was comprised of 12 replicate pots. Visual rating of the symptoms and pictures were taken after 6 weeks of seeding.

\section{Preparation of spore's inoculum}

Fusarium inoculum was prepared by inoculating liquid potato dextrose broth medium (PDB), 50ml in $150 \mathrm{ml}$ Erlenmeyer flasks, with mycelium discs from one-week old PDA culture. Flasks were incubated for five days at $27^{\circ} \mathrm{C}$ in a rotary shaker at $150 \mathrm{rpm}$. Microconidia were obtained by separation from the mycelium through filtration of the culture broth through three layers of sterile Miracloth. The conidial suspension was then precipitated at $4000 \mathrm{rpm}$ at $4{ }^{\circ} \mathrm{C}$; the low temperature facilitates better handling of the spore pellet when discarding the supernatant. The conidia were washed twice by resuspending and centrifuging the spores in $5 \mathrm{ml}$ of sterile distilled water. The final conidia concentration was adjusted to $10^{6} \mathrm{conidia} / \mathrm{ml}$ with sterile distilled water using counting chamber (Neubauer, Germany).

\section{Biocontrol test}

The biocontrol test for isolate TVH3 was performed according to the protocol of Marzano et al. (2013), where tomato seeds were surface disinfected in $5 \% \mathrm{NaOCl}$ for $15 \mathrm{~min}$, then washed three times in sterile distilled water and left to dry in sterile petri plate in laminar flow. The seeds were allowed to germinate by incubation in sterile petri plate with moisture filter paper at $25 \pm 1^{\circ} \mathrm{C}$ for 2 days. The germinated seeds were inoculated with TVH3 by immersion in a conidial suspension $\left(10^{7}\right.$ conidia $\left./ \mathrm{ml}\right)$ in sterile $2 \% \mathrm{CMC}$ solution for $1 \mathrm{~h}$ under continuous orbital shaking at 120rpm followed by air drying in the laminar flow. Seeding pots were filled with autoclaved Promix (seeding medium) and moistened with $50 \mathrm{ml}$ of a conidial suspension of FSK742 $\left(10^{6}\right.$ conidia/ $\mathrm{ml}$ ) and one tomato seed was placed in each pot, at a $1 \mathrm{~cm}$ depth. The pots were placed in a growth chamber and growth conditions were similar to the pathogenicity test. The plants were observed daily, and visual rating of the symptoms were recorded 
after one month of seeding. The bioassay included the following treatments: TVH3-coated seeds in FSK742-infected soil (the biocontrol test); TVH3non-coated seeds in FSK742-infected soil (only the pathogen) and TVH3-non-coated seeds in FSK742-non-infectedsoil (fungi-free conditions). The experiment was carried out in a completely randomized design and each treatment was comprised of 9 replicated pots.

To determine the number of TVH3 spores present as a seed coat after inoculation, a seed sample was shaken in sterile distilled water and an aliquot of the resulting suspension was diluted and plated onto DRBC medium which reduces colony diameters allowing the colonies to be easily recognized and counted (Rojo et al., 2007). The plates were incubated for 3 days at $25^{\circ} \mathrm{C}$ before counting Trichoderma colonies.

\section{$\underline{\text { Results }}$}

Molecular characterization and identification of selected cultures

The internal transcribed region of nuclear ribosomal DNA (ITS) has been widely accepted as a standard molecular marker for species discrimination on the fungal kingdom (Schoch et al., 2012 and Gokul Raj et al., 2014). The size of PCR products amplified with the primer pair ITS1-ITS4 rangedfrom 520 to 590bp (Fig. 1). On the basis of ITS sequences, selected fungi were identified to the species level by blasting the obtained sequences against deposited sequences in the NCBI database. Out of 6 isolated cultures, anisolate, named $\mathrm{TVH} 3$, was identified to the species level as $T$. virens. The ITS sequence of this isolate was submitted to NCBI and was assigned an accession number (GenBank accession number KU206725). Furthermore, the TrichOKEY system found five genus specific hallmarks in the ITS region confirming the identity of the isolate to be $T$. virens. Other identified isolates were irrelevant to this study and included Penicillium spp. Aspergillus spp. and one T. harzianum isolate.

\section{Antagonistic assays}

Antagonistic activities of the selected isolate were evaluated through several in vitro antagonistic assays. Growth rates of the pathogen in both presence and absence of this antagonist were recorded and evaluated.

\section{Dual culture test between TVH3 and F. oxysporum}

In the dual culture assay, the isolate TVH3 was tested against three different strains of $F$. oxysporum. Under tested conditions, F. oxysporum suffered a significant growth inhibition when cultured in the same plate with TVH3 (Fig. 2). Maximum growth inhibition was scored against strain FSK16 with $29.4 \%$ followed by FSK 737 and FSK742 with $23.4 \%$ (Fig. 2). The first apparent physical contact between TVH3 and the pathogens occurred within 2 days after inoculation.

The effect of TVH3 culture filtrate and VOCs on F. oxysporum growth and spore germination

The antifungal activity of TVH3 culture filtrate was assayed and the results (Fig. 2) revealed strong antifungal activity against all three $F$. oxysporum strains. Two different concentrations of TVH3 culture filtrate $(25 \%$ and $50 \%)$ were applied and growth inhibition of $F$. oxysporum ranged between $31-49 \%$ for the $25 \%$ concentration and between $36-56 \%$ for the $50 \%$ concentration. Furthermore, using the two before mentioned concentrations, $T$. virens culture filtrate had significantly reduced or totally prevented $F$. oxysporum's spore germination. T. virens culture filtrate scored $65 \%$ and $100 \%$ inhibition of $F$. oxysporum spore germination at the $25 \%$ and $50 \%$ concentrations, respectively (Fig. 3 ). Using the sandwich system for volatile interactions, it was found that TVH3's VOCs had also reduced F. oxysporum's spore germination by $19 \%$.

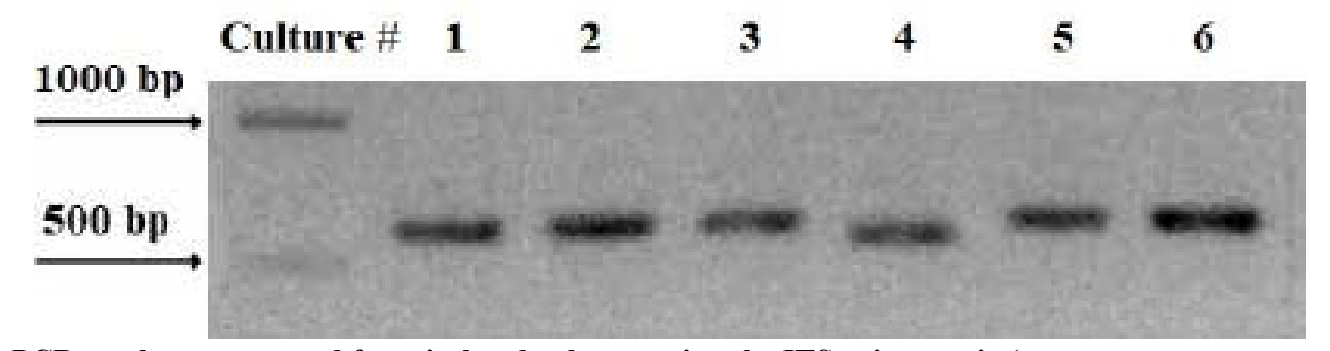

Fig. 1. PCR products generated from isolated cultures using the ITS primer pair (Numbers above each lane indicate the culture number. Identity of each fungus was obtained based on the alignment of their sequenced ITS regions with published sequences in the NCBI database. Samples were run on a 1.5\% agarose gel prepared in 1x TAE buffer). 

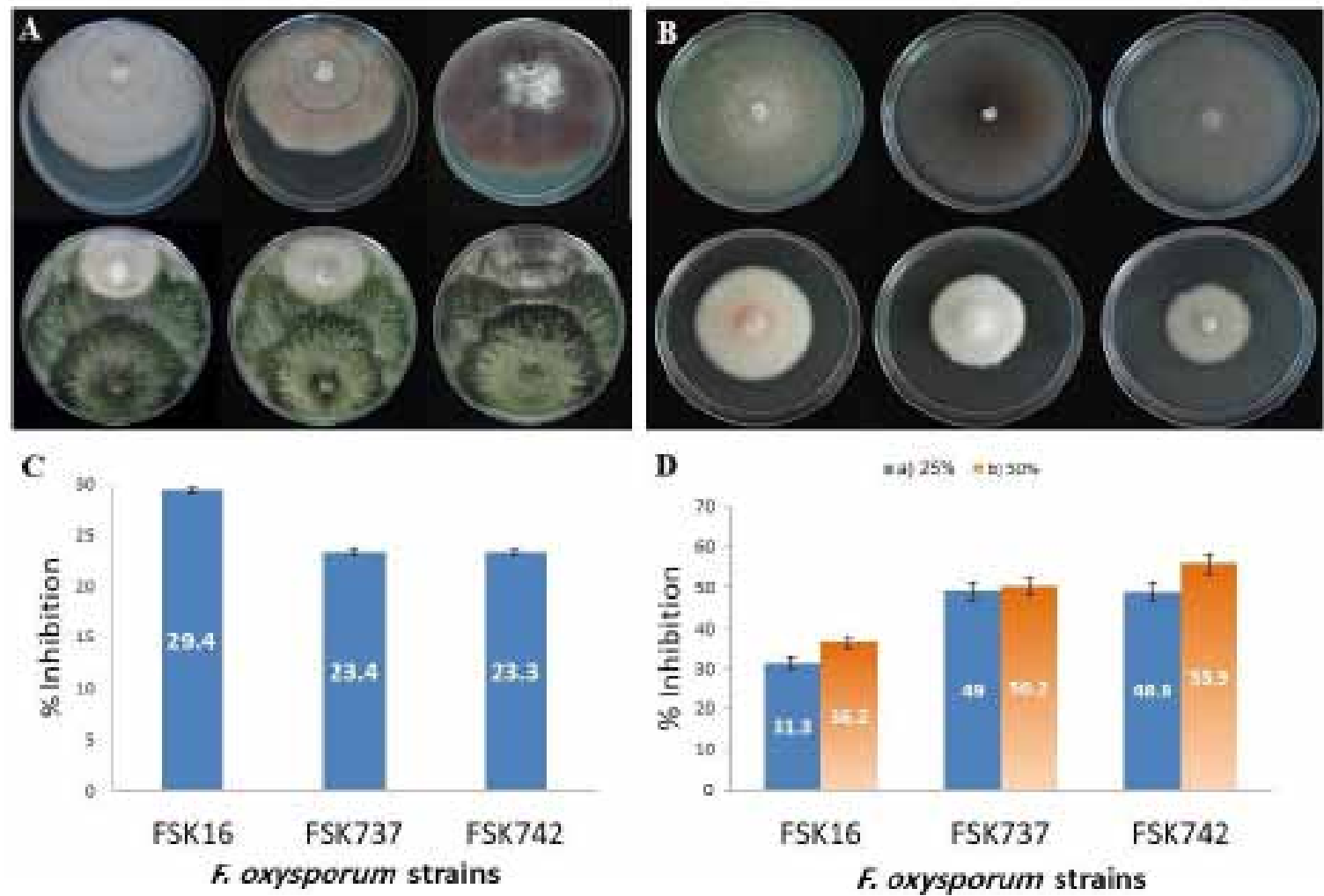

Fig. 2. A: Dual confrontation results 10 days post inoculation; B:F. oxysporum strains cultured on PDA amended with $50 \%$ T. virens culture filtrate; $C$ : growth inhibition ofF. oxysporum strains in dual cultures with $T$. virens TVH3; D: Growth inhibition of F. oxysporum strains cultured in media amended with $T$. virens TVH3 culture filtrate at two different concentrations 25 and $50 \%$. Petri plates in the top row represents the control and in the bottom row represents treatments. F. oxysporum strains from left to right are FSK16, FSK737 and FSK742.

The effect of Fusarium cell wall (FCW) and glucose as carbon sources on the BCA antifungal activity

When FCW was used as sole carbon source in TVH3 growth media, the antifungal activity of culture filtrate was significantly increased compared to the treatment where glucose was used as sole carbon source (Fig. 4). Therate of F. oxysporum growth inhibition had increased from $25 \%$ in the case of glucose to $52 \%$ in the case of FCW. This could be due to increase of mycotoxin secondary metabolites production or increase in themycolytic enzymes production or both.

Thermal stability of TVH3 culture filtrate

Both autoclaved and non-autoclaved (active) culture filtrates showed similar antifungal effects on $F$. oxysporum growth. Obtained results revealed that $T$. virens TVH3 culture filtrate retained $19 \%$ of its antifungal activity after severe thermal treatment (Fig. 4). This result suggests that TVH3 soluble metabolites are relatively heat stable.

The effects of $F$. oxysporum culture filtrate on $T$. virens (The reverse assay)

The reverse assay was carried out to test the tolerance of Trichoderma TVH3 to the antifungal properties of $F$. oxysporumculture filtrate. In this assay TVH3wascultured in PDA media amended with $F$. oxysporum culture filtrate at two different concentrations $25 \%$ and $50 \%$. Under the assay conditions, isolate TVH3 didn't suffer much from the presence of Fusarium soluble metabolite at both concentrations and managed to grow in rates comparable to the control treatment after 120-hour post inoculation (hpi) except with slight change in the culture morphology (Fig. 4). These results were confirmed by another qualitative assay, where culture broth (4 days old TMM) from both Trichoderma and Fusarium were sterilized by filtration, tested for absence of any CFUand each culture filtrate was inoculated 
with mycelium disc of the other fungus. Flasks were kept for additional 14 days at $25^{\circ} \mathrm{C}$ and 150 rpm. Resultsobtained showed that Fusariumwas completely unable to grow in TVH3 culture filtrate while Trichodermawas capable of growing in the Fusarium culture filtrate. These results suggest that $T$. virens TVH3 possesses high tolerance to $F$. oxysporum mycotoxic secondary metabolites.

\section{Pathogenicity and biocontrol assays}

The ability of $F$. oxysporum strains selected for this studyto induce Fusarium wilt to tomato plants were testedby growing tomato in a heavily infested soil with selected $F$. oxysporum strains. Results showed that the three strains were capableof inducing the Fusarium wilt to the tomato plants. However, the severity of the disease varied between the strains and the symptoms ranged between complete wilt (death), partial wilt,necrosis, stunted growth and discolorations in the form of yellowing and browning. Under our test conditions, strain FSK742 were the most virulent to tomato followed by FSK 16 and FSK737.Based on the pathogenicity test results, strain FSK742 was selected for the biocontrol assay which aimed to study TVH3 ability of protecting tomato seedlings from Fusarium wilt. The seed coating treatment resulted in at least 500 conidia per seed, as determined by $\mathrm{CFU}$ counts. Results revealed that the use of TVH3 as biofungicide effectively managed to provide protection against pathogenic $F$. oxysporum when applied as seed coat even when the soil was heavily infested with the pathogen.
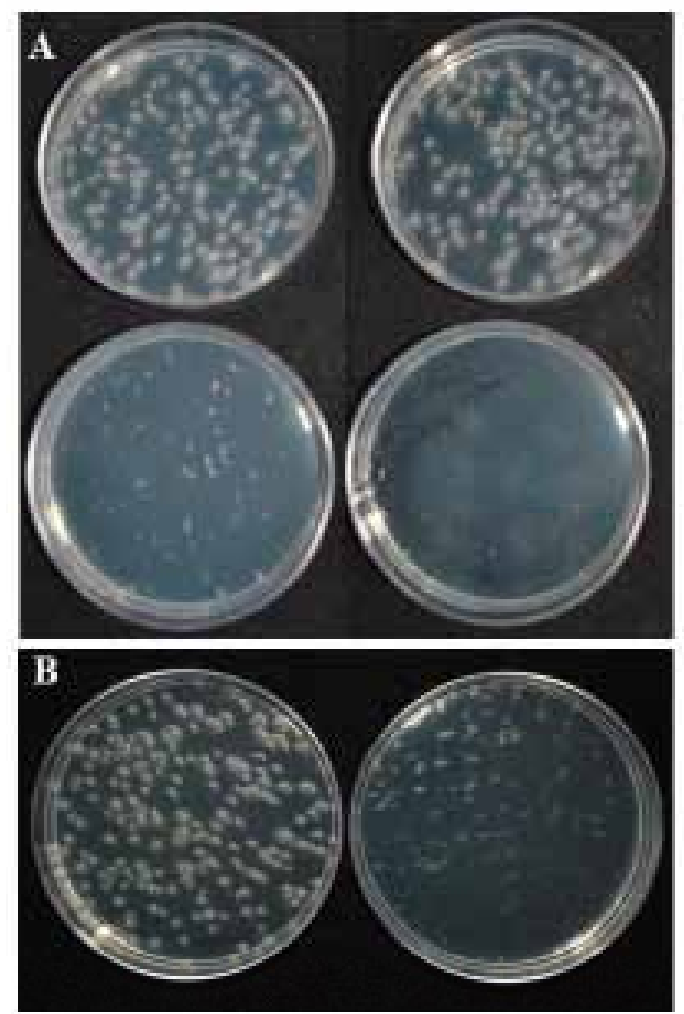
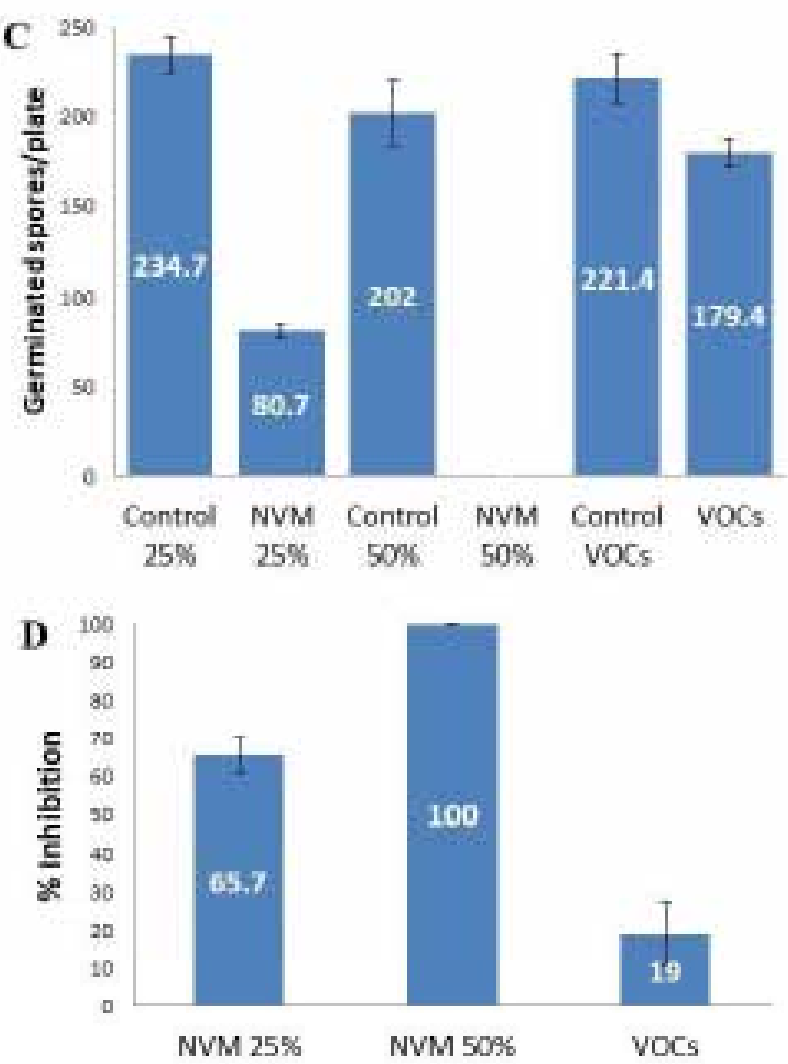

Fig. 3. Effect of $T$. virens TVH3 on $F$. oxysporum spore germination, A: $F$. oxysporum spores germination $24 \mathrm{hpi}$ on media amended with $T$. virens culture filtrate at two concentrations $25 \%$ (left) and $50 \%$ (right), top row represents control and the bottom row represents the treatments; B: The effect of $T$. virens VOCs on $F$. oxysporum spore germination, plate to the left represents control and the plate to the right represents the treatment; C: Germinated $F$. oxysporum spores per plate $24 \mathrm{hpi}$ when inoculated on media amended with $T$. virens culture filtrate at two concentrations $25 \%$ and $50 \%$; and $D$ : Inhibition ratio of $F$. oxysporum spore germination when confronted with TVH3 culture filtrate at two concentrations and VOCs. 

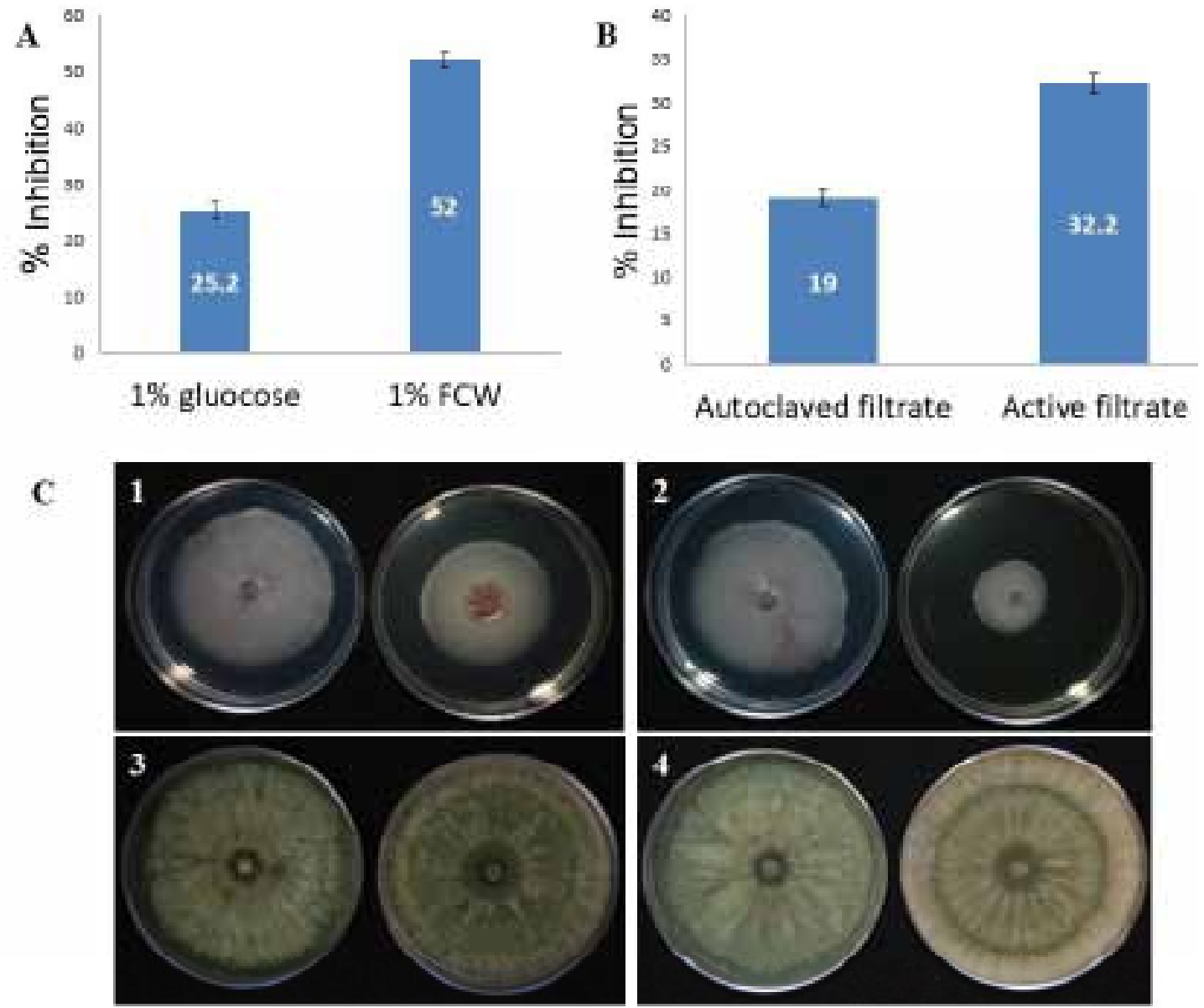

Fig. 4. A: The effect of Fusarium cell wall (FCW) and glucose as sole carbon sources in growth media on the antifungal activity of TVH3 culture filtrate; B: Thermal stability of the antifungal activity of TVH3 culture filtrate; $C$ : Forward and reverse assays $120 \mathrm{hpi}$ revealed that $F$. oxysporum is sensitive to the antifungal activity of TVH3 while TVH3 is resistant to the antifungal activity of $F$. oxysporum at both concentrations used (25 and 50\%) [Plates to the left are control and plates to the right are treatments; $1:$ F. oxysporum cultured on PDA amended with $25 \% T$. virens culture filtrate; 2: $F$. oxysporumcultured on PDA amended with $50 \% T$. virens culture filtrate; 3: $T$. virens cultured on PDA amended with $25 \%$ F . oxysporum culture filtrate and 4: $T$. virens cultured on PDA amended with $50 \%$ F. oxysporum culture filtrate].

\section{Discussion}

The biocontrol phenomenon by Trichoderma spp. is a complex process that involve the secretion of mycolyticenzymes, toxic secondary metabolites and volatile organic compounds (Vinale et al., 2006). Trichoderma spp. are capable of producing plenty of chemically diverse secondary metabolites that exhibit antimicrobial activities such as peptaibols, gliotoxin, gliovirin, polyketides, pyrones and terpenes (Hermosa et al., 2014). Successful antagonism by Trichoderma spp. requires synergism between mycoparasitism and antibiosis against their fungal pathogens. The lytic enzymes work result in weakening the cell wall of the fungal prey which improves the rate of diffusion of the antibiotic towards the cell surface (Schirmbock et al., 1994). Such synergistic cooperation between different mechanisms maximizes the performance of the BCA (Keswani et al., 2014).

In this study, we used direct confrontations between the BCA and different strains of the soil borne pathogen because direct confrontation is a powerful tool to study fungal interactions and the phenomenon of mycoparasitism and to screen for promising BCAs (Siameto et al., 2010; Vieira et al., 2013; Carvalho et al., 2014 and Steindorff et al., 2014). Competition for nutrients is a major mechanism used by $T$. harzianum to control $F$. oxysporum $f$. sp. melonis (Sivan \& Chet, 
1989a). Since both the BCAs and their targeted preys alongside other microorganisms share the same ecological niche, competition against each other's for the available space and nutrients is a normal phenomenon. Dual confrontations results between TVH3 and $F$. oxysporum revealed the quick and powerful encroachment of $T$. virnes towards $F$. oxysporum which was far stronger than the pathogen towards the BCA. The BCA's quick and powerful growth resulted in quickly taking over of the most available space in the Petri plates and $F$. oxysporum was confined to a small area unable to extend its growth after the third day of co-incubation with TVH3.

FCW highly induced theanti-fungal activity of TVH3 compared to glucose when they were used individually as sole carbon source in $T$. virens growth medium. Such result is in agreement with other studies suggesting that fungal cell walls can act as inducers of mycolytic enzymes synthesis (Sivan \& Chet, 1989b; Kucuk \& Kivanc, 2004 and Kumar et al., 2012). Moreover, English et al. (1971) reported that enzyme's secretion is not proportional to fungal growth; rather, enzyme secretion is induced or down-regulated by environmental parameters. In this context, it would be important to note that Trichoderma spp. sense the presence of competitive fungi though constitutively secretion of a variety of lytic enzymes and detecting their degraded cell wall components (Keswani et al., 2014). Our results are similar to that obtained by Sivan \& Chet (1989b) in which they reported high levels of chitinase and glucanase were produced by $T$. harzianum when grown on Rhizoctoniasolani mycelia. Also similar findings were obtained by Kucuk \& Kivanc (2004) as they obtained higher levels of chitinase and glucanase from T. harzianum $\mathrm{T} 15$ when they used Gaeumannomyces graminis var. tritici, Fusarium culmorum and Fusariumm oniliforme cell wall as carbon source.

Among the good characteristics of fungal BCAs is their ability to overcome the fungistasis effects induced by competing species in the environment. Our results suggest that $T$. virens TVH3 possess natural immunity against $F$. oxysporum-released antifungal compounds. In agreement with our results, Chet et al. (1997) reported that Trichoderma spp. possess natural resistance to many toxic compounds, including herbicides, fungicides and pesticides, which is of particular importance for using them in a more comprehensive integrated pest management programs alongside other chemical treatments.

\section{Conclusion}

The current study aimed to evaluate the efficiency of new isolate of Trichoderma as BCAs against the soil-borne fungal pathogen $F$. oxysporum and indicates the need of finding and development new Trichoderma based BCAs to serve environmentfriendly approach for pathogens control. The evaluated isolate displayed promising antagonistic activities against $F$. oxysporum during the in vitro antagonistic assays and managed to protect tomato plantsseeded in heavily infested soil with virulent strain of the pathogen. Despite that BCAs still have their limitations with environmental factors; the growing demand for biocontrol products among the growers makes the future outlooks of biocontrol of plant diseases bright and promising. The growing organics markets, increased public attention to environmental issues, workers safety and liability costs and finally pathogenic strains resistance management problems are all factors contributing in favor of BCAs market development.

Acknowledgment: This work was conducted during Fulbright scholarship in Pennsylvania State University and therefore, Alfiky is grateful for the Fulbright program and the Binational Fulbright Commission in Egypt for supporting his scholarly visit to Penn State.

\section{References}

Aktar, W., Sengupta, D. and Chowdhury, A. (2009) Impact of pesticides use in agriculture: Their benefits and hazards. Interdiscip. Toxicol. 2, 1-12. DOI: $10.2478 / \mathrm{v} 10102-009-0001-7$

Benítez, T., Rincón, A.M., Limón, M.C. and Codón, A.C. (2004) Biocontrol mechanisms of Trichoderma strains. Int. Microbiol. 7, 249-260. DOI: 1139-6709

Carvalho, D.D.C., Lobo Júnior, M., Martins, I., Inglis, P.W. and Mello, S.C.M. (2014) Biological control of Fusarium oxysporum $\mathrm{f}$. sp . phaseoli by Trichoderma harzianum and its use for common bean seed treatment. Trop. Plant Pathol. 39, 384-391.

Chet, I., Inbar, J. and Hadar, I. (1997) Fungal antagonists and mycoparasites. In: " The Mycota 
IV: Environmental and Microbial Relationships", Wicklow, D.T. and Söderström, B. (Ed.), pp. 165184, Springer, Berlin.

Damalas, C. (2009) Understanding benefits and risks of pesticide use. Sci. Res. Essay, 4, 945-949.

Dennis, C. and Webster, J. (1971) Antagonistic properties of species-groups of Trichoderma. Trans. Br. Mycol. Soc. 57, 41-IN4. DOI: 10.1016/ S0007-1536(71)80078-5.

Druzhinina, I.S., Kopchinskiy, A.G., Komoń, M., Bissett, J., Szakacs, G. and Kubicek, C.P. (2005) An oligonucleotide barcode for species identification in Trichoderma and Hypocrea. Fungal Genet. Biol. 42, 813-828. DOI: 10.1016/j.fgb.2005.06.007

English, P.D., Jurale, J.B. and Alpersheim, P. (1971) Host-pathogen interactions. Plant Physiol. 47(16), 916-926.

Geraldine, A.M., Lopes, F.A.C., Carvalho, D.D.C., Barbosa, E.T., Rodrigues, A.R., Brandão, R.S., Ulhoa, C.J. and Lobo Junior, M. (2013) Cell walldegrading enzymes and parasitism of sclerotia are key factors on field biocontrol of white mold by Trichoderma spp. Biol. Control, 67, 308-316. DOI: 10.1016/j.biocontrol.2013.09.013

GokulRaj, K., Sundaresan, N., Ganeshan, E.J., Rajapriya, P., Muthumary, J., Sridhar, J. and Pandi, M. (2014) Phylogenetic reconstruction of endophytic fungal isolates using internal transcribed spacer 2 (ITS2) region. Bioinformation, 10, 320-8. DOI: $10.6026 / 97320630010320$

Hajieghrari, B., Torabi-giglou, M. and Mohammadi, M.R. (2008) Biological potantial of some Iranian Trichoderma isolates in the control of soil borne plant pathogenic fungi. African J. Biotechnol. 7, 967-972.

Harman, G.E., Howell, C.R., Viterbo, A., Chet, I. and Lorito, M.(2004) Trichoderma species opportunistic, avirulent plant symbionts. Nat. Rev. Microbiol. 2, 43-56. DOI: 10.1038/nrmicro797

Hermosa, R., Cardoza, R.E., Rubio, M.B., Gutiérrez, S. and Monte, E. (2014) Secondary metabolism and antimicrobial metabolites of Trichoderma. In: "Biotechnology and Biology of Trichoderma", pp. 125-137. DOI: 10.1016/B978-0-444-59576$8.00010-2$

Egypt. J. Bot. 59, No.1 (2019)
Hoitink, H.J., Madden, L.V. and Dorrance, E. (2006) Interactions between the host, the pathogen, the biocontrol agent, and soil organic matter quality. Phytopathology, 96, 186-189. DOI: 10.1094/ PHYTO-96-0186

Hollomon, D.W. (2015) Fungicide Resistance: Facing the challenge - a review. Plant Prot. Sci. 51, 170176. DOI: $10.17221 / 42 / 2015$-PPS

Ignjatov, M., Milosevic, D., Nikolic, Z., GvozdanovicVarga, J., Jovicic, D. and Zdjelar, G. (2012) Fusarium oxysporum as causal agent of tomato wilt and fruit rot. Pestic. i fitomedicina, 27, 25-31. DOI: 10.2298/PIF1201025I

Kai, M., Effmert, U., Berg, G. and Piechulla, B. (2007) Volatiles of bacterial antagonists inhibit mycelial growth of the plant pathogen Rhizoctonia solani. Arch. Microbiol. 187, 351-360. DOI: 10.1007/ s00203-006-0199-0

Keswani, C., Mishra, S., Sarma, B.K., Singh, S.P. and Singh, H.B. (2014) Unraveling the efficient applications of secondary metabolites of various Trichoderma spp. Appl. Microbiol. Biotechnol. 98, 533-544. DOI: 10.1007/s00253-013-5344-5

Koh, D. and Jeyaratnam, J.(1996) Pesticides hazards in developing countries. Sci. Total Environ. 188. DOI: 10.1016/0048-9697(96)05279-5

Kucuk, C. and Kivanc, M.(2004) In vitro antifungal activity of strains of Trichoderma harzianum. Turk. J. Biol. 28, 111-115.

Kumar, K., Amaresan, N., Bhagat, S., Madhuri, K. and Srivastava, R.C. (2012) Isolation and characterization of Trichoderma spp. for antagonistic activity against root rot and foliar pathogens. Indian J. Microbiol. 52, 137-144. DOI: 10.1007/s12088-011-0205-3

Lucas, J.A., Hawkins, N.J. and Fraaije, B.A. (2015) The evolution of fungicide resistance, Advances in Applied Microbiology. Elsevier Ltd. DOI: 10.1016/ bs.aambs.2014.09.001

Marzano, M., Gallo, A. and Altomare, C. (2013) Improvement of biocontrol efficacy of Trichoderma harzianum vs. Fusarium oxysporum f. sp. lycopersici through UV-induced tolerance to fusaric acid. Biol. Control, 67, 397-408. DOI: 0.1016/j.biocontrol.2013.09.008 
McGovern, R.J. (2015) Management of tomato diseases caused by Fusarium oxysporum. Crop Prot. 73, 7892. DOI: $10.1016 /$ j.cropro.2015.02.021

Nawrocka, J. and Małolepsza, U. (2013) Diversity in plant systemic resistance induced by Trichoderma. Biol. Control, 67, 149-156. DOI: 10.1016/j. biocontrol.2013.07.005

Ozbay, N., Newman, S.E. and Brown, W.M. (2004) The effect of the Trichoderma harzianum strains on the growth of tomato seedlings. Acta Hort. 636, 131-135.

Pal, K. and Gardener, B. (2006) Biological control of plant pathogens. Plant Heal. Instr. 1-25. DOI: 10.1094/PHI-A-2006-1117-02.Biological

Penttilä, M., Nevalainen, H., Rättö, M., Salminen, E. and Knowles, J. (1987) A versatile transformation system for the cellulolytic filamentous fungus Trichoderma reesei. Gene, 61, 155-164. DOI: 10.1016/0378-1119(87)90110-7

Ploetz, R.C. (2015) Fusarium Wilt of Banana. Phytopathology, 105, 1512-1521. DOI: 10.1094/ PHYTO-04-15-0101-RVW

Ridgway, R.L., Tinney, J.C., MacGregor, J.T. and Starler, N.J. (1978) Pesticide use in agriculture. Environ. Health Perspect. 27, 103-112. DOI: 10.1289/ehp.7827103

Rojo, F.G., Reynoso, M.M., Ferez, M., Chulze, S.N. and Torres, A.M. (2007) Biological control by Trichoderma species of Fusarium solani causing peanut brown root rot under field conditions. Crop Prot. 26, 549-555. DOI: 10.1016/j. cropro.2006.05.006

Rowe, R.C. (1980) Isolates causing crown and root rot of greenhouse and field-grown tomatoes in north America and Japan. Phytopathology, DOI: 10.1094/Phyto-70-1143

Schirmbock, M., Lorito, M., Wang, Y.L., Hayes, C.K., Arisan-Atac, I., Scala, F., Harman, G.E. and Kubicek, C.P. (1994) Parallel formation and synergism of hydrolytic enzymes and peptaibol antibiotics, molecular mechanisms involved in the antagonistic action of Trichoderma harzianum against phytopathogenic fungi. Appl. Environ. Microbiol. 60, 4364-4370. DOI: 7811076
Schoch, C.L., Seifert, K.A., Huhndorf, S., Robert, V., Spouge, J.L., Levesque, C.A., Chen, W., Consortium, F.B., Bolchacova, E., Voigt, K., Crous, P.W., Miller, A.N., Wingfield, M.J., Aime, M.C., An, K.D., Bai, F.Y., Barreto, R.W., Begerow, D., Bergeron, M.J., Blackwell, M., Boekhout, T., Bogale, M., Boonyuen, N., Burgaz, A.R., Buyck, B., Cai, L., Cai, Q., Cardinali, G., Chaverri, P., Coppins, B.J., Crespo, A., Cubas, P., Cummings, C., Damm, U., De Beer, Z.W., de Hoog, G.S., Del-Prado, R., Dentinger, B., DieguezUribeondo, J., Divakar, P.K., Douglas, B., Duenas, M., Duong, T.A., Eberhardt, U., Edwards, J.E., Elshahed, M.S., Fliegerova, K., Furtado, M., Garcia, M.A., Ge, Z.W., Griffith, G.W., Griffiths, K., Groenewald, J.Z., Groenewald, M., Grube, M., Gryzenhout, M., Guo, L.D., Hagen, F., Hambleton, S., Hamelin, R.C., Hansen, K., Harrold, P., Heller, G., Herrera, C., Hirayama, K., Hirooka, Y., Ho, H.M., Hoffmann, K., Hofstetter, V., Hognabba, F., Hollingsworth, P.M., Hong, S.B., Hosaka, K., Houbraken, J., Hughes, K., Huhtinen, S., Hyde, K.D., James, T., Johnson, E.M., Johnson, J.E., Johnston, P.R., Jones, E.B.G., Kelly, L.J., Kirk, P.M., Knapp, D.G., Koljalg, U., Kovacs, G.M., Kurtzman, C.P., Landvik, S., Leavitt, S.D., Liggenstoffer, A.S., Liimatainen, K., Lombard, L., Luangsa-ard, J.J., Lumbsch, H.T., Maganti, H., Maharachchikumbura, S.S.N., Martin, M.P., May, T.W., McTaggart, AR., Methven, A.S., Meyer, W., Moncalvo, J.M., Mongkolsamrit, S., Nagy, L.G., Nilsson, R.H., Niskanen, T., Nyilasi, I., Okada, G., Okane, I., Olariaga, I., Otte, J., Papp, T., Park, D., Petkovits, T., Pino-Bodas, R., Quaedvlieg, W., Raja, H.A., Redecker, D., Rintoul, T.L., Ruibal, C., Sarmiento-Ramirez, J.M., Schmitt, I., Schussler, A., Shearer, C., Sotome, K., Stefani, F.O.P., Stenroos, S., Stielow, B., Stockinger, H., Suetrong, S., Suh, S.O., Sung, G.H., Suzuki, M., Tanaka, K., Tedersoo, L., Telleria, M.T., Tretter, E., Untereiner, W.A., Urbina, H., Vagvolgyi, C., Vialle, A., Vu, T.D., Walther, G., Wang, Q.M., Wang, Y., Weir, B.S., Weiss, M., White, M.M., Xu, J., Yahr, R., Yang, Z.L., Yurkov, A., Zamora, J.C., Zhang, N., Zhuang, W.Y. and Schindel, D. (2012) Nuclear ribosomal internal transcribed spacer (ITS) region as a universal DNA barcode marker for Fungi. Proc. Natl. Acad. Sci. U.S.A., 109, 1-6. DOI: 10.1073/pnas.1117018109

Siameto, E.N., Okoth, S., Amugune, N.O. and Chege, N.C. (2010) Antagonism of Trichoderma harzianum isolates on soil borne plant pathogenic fungi from Embu District, Kenya. Yeast, 1, 47-54. 
Sivan, A. and Chet, I. (1987) Biological control of Fusarium crown rot of tomato by Trichoderma hazianum under field condition. Plant Dis. DOI: 10.1094/PD-71-0587

Sivan, A. and Chet, I. (1989a) The possible role of competition between Trichoderma harzianum and Fusarium oxysporum on rhizosphere colonization. Phytopathology, DOI: 10.1094/Phyto-79-198

Sivan, A. and Chet, I. (1989b) Degradation of fungal cell walls by lytic enzymes of Trichoderma harzianum. Microbiology, 135, 675-682. DOI: 10.1099/00221287-135-3-675

Snyder, S.N.S. (1974) Persistance pf Fusarium oxysporum f. sp. vasinfectum in Fields in the Absence of Cotton. Phytopathology, 65, 190-196.

Steindorff, A.S., Ramada, M.H.S., Coelho, A.S.G., Miller, R.N.G., Pappas, G.J., Ulhoa, C.J. and Noronha, E.F. (2014) Identification of mycoparasitism-related genes against the phytopathogen Sclerotinia sclerotiorum through transcriptome and expression profile analysis in Trichoderma harzianum. BMC Genomics, 15, 204. DOI: $10.1186 / 1471-2164-15-204$

Vieira, P.M., Coelho, A.S.G., Steindorff, A.S., de Siqueira, S.J.L., Silva, R.D.N. and Ulhoa, C.J. (2013) Identification of differentially expressed genes from Trichoderma harzianum during growth on cell wall of Fusarium solani as a tool for biotechnological application. BMC Genomics, 14, 177. DOI: $10.1186 / 1471-2164-14-177$

Vinale, F., Manganiello, G., Nigro, M., Mazzei, P., Piccolo, A., Pascale, A., Ruocco, M., Marra, R., Lombardi, N., Lanzuise, S., Varlese, R., Cavallo, P., Lorito, M. and Woo, S. (2014) A novel fungal metabolite with beneficial properties for agricultural applications. Molecules, 19, 9760-9772. DOI: 10.3390/molecules 19079760

Vinale, F., Marra, R., Scala, F., Ghisalberti, E.L., Lorito, M. and Sivasithamparam, K. (2006) Major secondary metabolites produced by two commercial Trichoderma strains active against different phytopathogens. Lett. Appl. Microbiol. 43, 143-148. DOI: $10.1111 / \mathrm{j} .1472-765 X .2006 .01939 . x$

Wauchope, R.D. (1978) The pesticide content of surface water draining from agricultural fields. J. Environ. Qual. 7, 459. DOI: 10.2134/ jeq1978.00472425000700040001x

White, T.J., Bruns, T.D., Lee, S.B. and Taylor, J.W. (1990) Amplification and direct sequencing of fungal ribosomal RNA genes for phylogenetics. In: "PCR Protocols: A Guide to Methods and Applications", M.A. Innis, D.H. Gelfand, J.J. Sninsky, and T.J. White (Ed.), pp. 315-322. Academic Press, San Diego, California, USA.

(Received 18/4/2017; accepted 11/10/2018)

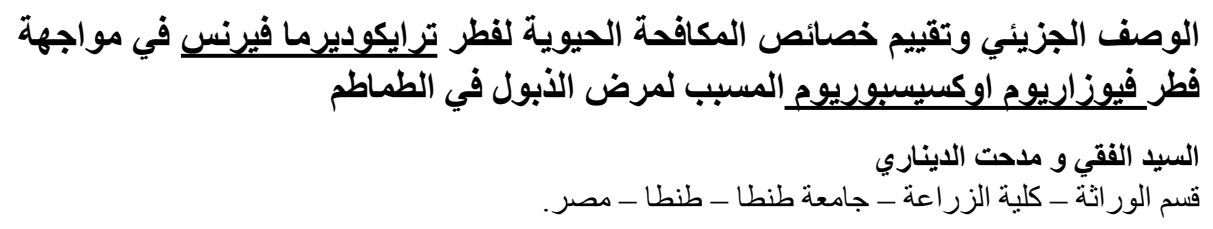

في محاولة لإيجاد عو امل جديدة تستخدم في المكافحة الحيوية ذات قدرة عالية على مواجهة وتثبيط فطريات

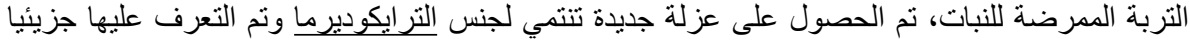

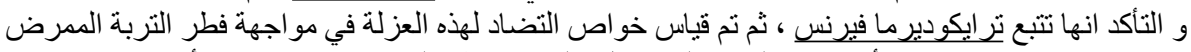

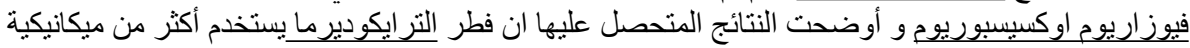

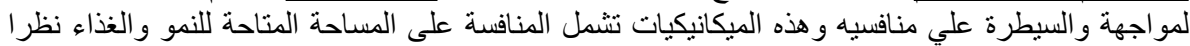

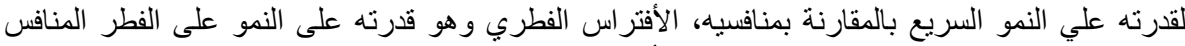

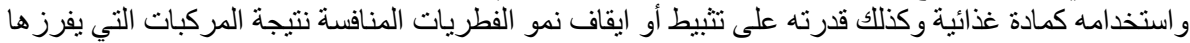

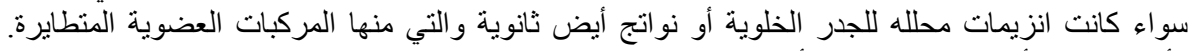

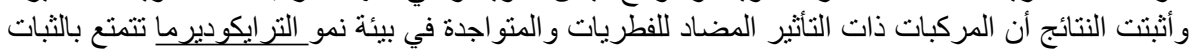

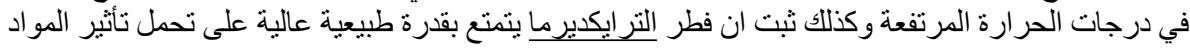

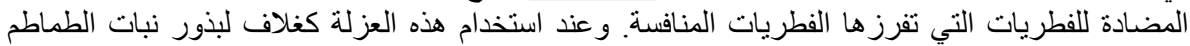

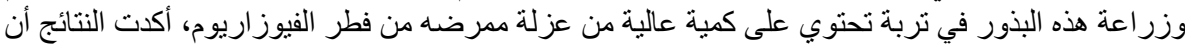

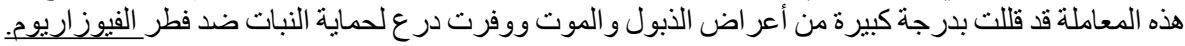

